\title{
Maternal inheritance in the efficiency of use of Azospirillum brasilense in maize
}

\section{Herança materna na eficiência de uso de Azospirillum brasilense em milho}

\author{
Rafael Almeida MICHELLI'; Flávia Alves Marques da SILVA²; Gustavo Vitti MÔRO³ \\ 1 Engenheiro Agrônomo, Universidade Estadual Paulista "Júlio de Mesquita Filho", Faculdade de Ciências Agrárias e \\ Veterinárias, Câmpus de Jaboticabal, "Rafael A. M." rafael.a.m.1@hotmail.com \\ 2 Doutora em Agronomia - Genética e Melhoramento de Plantas, Universidade Estadual Paulista "Júlio de Mesquita Filho", \\ Faculdade de Ciências Agrárias e Veterinárias, Câmpus de Jaboticabal, flavia_alvesms@hotmail.com \\ ${ }^{3}$ Autor para correspondência - Professor Associado, Universidade Estadual Paulista "Júlio de Mesquita Filho", Faculdade de \\ Ciências Agrárias e Veterinárias, Câmpus de Jaboticabal, Departamento de Ciências da Produção Agrícola, \\ gv.moro@unesp.br
}

Recebido em: 30-05-2020; Aceito em: 29-06-2020

\begin{abstract}
The maize crop demands high nitrogen input. However, Brazilian soils are generally deficient in this element. The use of associative bacteria, such as Azospirillum brasilense, can benefit agricultural systems that use low nitrogen levels. This study analyzes the occurrence of maternal inheritance in traits of maize genotypes for the efficiency of response to Azospirillum brasilense. For that, we used 132 treatments consisting of 66 crosses in complete diallel scheme with reciprocals. We evaluated two experiments in the same area and under the same conditions. We performed one experiment without nitrogen topdressing / with Azospirillum brasilense inoculation and another with nitrogen topdressing / without Azospirillum brasilense inoculation. These experiments took place in the second crop of 2017, in a randomized block design with two replicates. After obtaining the data, we estimated the efficiencies for the use of Azospirillum brasilense by adapting the Fischer model. From these data, we conducted analysis of variance, $\mathrm{t}$ test, and diallel analysis, thus estimating maternal inheritance. The evaluated traits showed no maternal inheritance, being governed by nuclear genes. Most genotypes were efficient for the use of $A$. brasilense, for all traits.
\end{abstract}

Additional keywords: combining ability; diallel analysis; diazotrophic bacteria; Zea mays L.

\section{Resumo}

O nitrogênio é um dos elementos mais exigidos pela cultura do milho, sendo geralmente deficiente nos solos Brasileiros. O uso de bactérias associativas, como Azospirillum brasilense, pode ser benéfico para sistemas agrícolas sob baixa utilização de nitrogênio. O objetivo do trabalho foi verificar a ocorrência de herança materna para a eficiência de resposta ao Azospirillum brasilense, em caracteres de genótipos de milho. Foram utilizados 132 tratamentos, compostos por 66 cruzamentos obtidos em esquema dialélico completo e com recíprocos, sendo avaliados dois experimentos na mesma área e sob as mesmas condições, sendo um experimento sem adubação nitrogenada de cobertura e com inoculação com Azospirillum brasilense e outro com adubação nitrogenada de cobertura e sem aplicação de Azospirillum brasilense. Os experimentos foram conduzidos na segunda safra de 2017, no delineamento experimental de blocos ao acaso com duas repetições. Com os dados obtidos foram estimadas as eficiências ao uso de Azospirillum brasilense, com a adaptação do modelo de Fischer. A partir desses dados foram realizadas análise de variância, teste t e análise dialélica, estimando-se a herança materna. Não houve herança materna para as características avaliadas, sendo as mesmas governadas por genes nucleares. A maioria dos genótipos foi eficiente ao uso de $A$. brasilense, para todas as características.

Palavras-chave adicionais: análise dialélica; bactérias diazotróficas; capacidade de combinação; Zea mays L.

\section{Introduction}

Maize is a cereal of great importance worldwide, with application in human food and in industry. Its main purpose is to supplement animal diets. Brazil is the third largest maize producer in the world, with an average yield (including the first, second, and third crops) of $5,719 \mathrm{~kg} \mathrm{ha}^{-1}$ (CONAB, 2020).

A proper supply of nutrients is necessary for this crop to express its maximum yield potential. Among these nutrients stand out nitrogen (Akhtar et al., 2015; Wasaya et al., 2017). Despite the abundance of atmospheric nitrogen, plants do not assimilate it naturally. However, this assimilation can take place from biological fixation through the action of microorganisms (Montañez et al., 2008). Associative bacteria, such as those of the genus Azospirillum, can benefit maize plants, including providing part of the necessary nitrogen (Hungria, 2011; Buzinaro et al., 2018; Revolti et al., 2018). 
In genetic breeding programs, diallel crosses assist in determining the best combinations between parents and in population segregation through the recombination of genetic variability (Griffing, 1956). These crosses allow understanding the inheritance of traits. The transmission of traits to the progenies occurs from nuclear genes or cytoplasmic genes, the latter corresponding to maternal inheritance (Cruz \& Regazzi, 2014). Knowledge of these effects is fundamental for the development and success of a genetic breeding program because, when there is maternal inheritance, the female parent will directly interfere with the expression of the traits of the descendants.

This study analyzes the occurrence of maternal inheritance in traits of maize genotypes for the efficiency of response to $A$. brasilense, addressing the genotypes most responsive to this bacterium.

\section{Material and methods}

We conducted the experiment in an experimental rural area in Jaboticabal city, São Paulo State, Brazil (2115'22"' S latitude and 48 18'58" W longitude; average altitude of 575 meters). According to the Köppen Classification (1948), the climate of the region is type Aw, tropical with rainy summers and dry winters. The average annual rainfall is $1,425 \mathrm{~mm}$, with rainfall concentration in the summer. The relief is smooth wavy and the soil is a eutrophic Red Latosol.

We used 132 genotypes as treatments, consisting of 66 crosses in complete diallel scheme with reciprocals. For that, we used as parents 12 synthetics from the company Phoenix Agrícola Ltda. The 132 treatments took place in the second crop of 2017. The experimental design was a randomized block with two replicates, with experimental plots consisting of two 5-m long rows. Spacing was 0.50 meter between rows and 0.33 meter between plants, totaling a final population of 60,000 plants per hectare.

To evaluate the response to Azospirillum brasilense, we installed two experiments in the same area and under the same conditions, namely:

Experiment 1 - With Azospirillum: without nitrogen topdressing and with $A$. brasilense inoculation.

Experiment 2 - Without Azospirillum: with nitrogen topdressing and without $A$. brasilense inoculation.

We used a plot seeder for sowing, applying $350 \mathrm{~kg} \mathrm{ha}^{-1}$ of 8-28-16 (NPK) as base fertilizer. We controlled pests and weeds according to the needs and recommendations for maize cultivation. For nitrogen topdressing, we used urea in the amount necessary to supply $140 \mathrm{~kg} \mathrm{ha}^{-1}$ nitrogen. For the inoculation of genotypes with Azospirillum brasilense, we applied the commercial product (Qualifix Gramínea®) via soil, at a dose of $600 \mathrm{~mL} \mathrm{ha}^{-1}$.

In each experimental plot, we assessed the following characteristics:

a) Plant height, measuring the distance from the ground to the flag leaf insertion $(\mathrm{cm})$;

b) Ear height, measuring the distance from the ground to the main ear insertion $(\mathrm{cm})$;

c) Relative ear position, resulting from the relationship between ear height and plant height; d) Grain yield, correcting the quantity of grains produced in the plot to $13 \%$ moisture and converting the values to tons per hectare $\left(\mathrm{t} \mathrm{ha}^{-1}\right)$.

From these data, we performed analysis of variance, estimating the efficiency of the response to inoculation with Azospirillum brasilense for each genotype and for all traits by applying the Student t test and the diallel analysis.

We estimated the efficiency in the use of Azospirillum brasilense $(\mathrm{E})$ for the traits by contrasting the data from the two experiments. For that, we used the same principles of Fischer et al. (1983), who estimated the efficiency in the use of nutrients. Thus, we obtained the following expression:

$E Y_{n}=\left[\frac{Y_{n}\left(\frac{C}{N}\right)}{Y_{n}\left(\frac{C}{A z}\right)}\right] \times\left[\frac{Y\left(\frac{C}{N}\right)}{Y\left(\frac{C}{A z}\right)}\right]$

Wherein: $E Y_{n}$ is the efficiency of response to $A$. brasilense for the $Y$-th trait of the $n$-th genotype;

$Y_{n}\left(\frac{C}{N}\right)$ is the mean for the $Y$-th trait of the $n$-th genotype, with application of nitrogen topdressing;

$Y_{n}\left(\frac{C}{A z}\right)$ is the mean for the $Y$-th trait of the $n$-th genotype, with $A$. brasilense inoculation;

$Y\left(\frac{C}{N}\right)$ is the general mean for the $Y$-th trait, with application of nitrogen topdressing;

$Y\left(\frac{C}{A Z}\right)$ is the general mean for the $Y$-th trait, with A. brasilense inoculation.

We determined the efficiency for the traits from the nitrogen: Azospirillum brasilense ratio. To assess the reliability of the genotypes in being efficient to $A$. brasilense, we used the t test, looking for differences between the means of the genotypes and the comparative parameters 0 and 1 . Values less than or equal to 1 indicate efficient genotypes, and higher values indicate nonefficient genotypes.

We performed the diallel analysis following the model I of method 3 of Griffing (1956), estimating the general and specific combination ability and the reciprocal effect. The statistical model is given by:

$Y_{i j}=m+g_{i}+g_{j}+s_{i j}+r_{i j}+e_{i j}$

Wherein: $Y_{i j}$ is the mean value of $\mathrm{F}_{1}$ hybrids and reciprocals $(i, j=1,2, \ldots, p) ; m$ is the general mean; $g_{i}$ and $g_{j}$ are the effects of the general combining ability of the $i$-th and $j$-th parent, respectively; $s_{i j}$ is the effect of the specific combining ability for crosses between parents of order $i$ and $j ; r_{i j}$ is the reciprocal effect that measures the differences provided by the parent $i$ or $j$, when used as male or female in the $i j$ cross, allowing to infer about the existence of maternal inheritance; $e_{i j}$ is the mean experimental error. By this methodology, the comparison of crosses with their reciprocals allows inferring maternal inheritance for the trait when the source of variation of the reciprocal effect is significant (Griffing, 1956). 


\section{Results and discussion}

In the analysis of variance, the results of the $F$ test did not differ for the 132 genotypes regarding the efficiency of use of Azospirillum brasilense (E) for all traits under study. The coefficients of variation were acceptable for all traits, with minimum and maximum values of 9.17 and 32.81 , respectively, for the efficiency for relative ear position (ERP) and the efficiency for grain yield (EGY) (Table 1).

Table 1 - Summary of the analysis of variance of the efficiency of use of Azospirillum brasilense for plant height, ear height, ear position and grain yield of 132 maize genotypes.

\begin{tabular}{lccccc}
\hline \multirow{2}{*}{${ }^{1} S V$} & \multirow{2}{*}{${ }^{2} \mathrm{DF}$} & \multicolumn{4}{c}{ Mean squares } \\
\cline { 3 - 6 } & & ${ }^{4} \mathrm{EPH}$ & ${ }^{5} \mathrm{EEH}$ & ${ }^{6} \mathrm{ERP}$ & ${ }^{7} \mathrm{EPG}$ \\
\hline Treatment & 131 & $00.0087^{\text {ns }}$ & $00.0209^{\text {ns }}$ & $00.0071^{\text {ns }}$ & $00.4180^{\text {ns }}$ \\
Error & 131 & 00.0107 & 00.0240 & 00.0087 & 00.4062 \\
Mean & - & 01.1234 & 01.1463 & 01.0191 & 01.9425 \\
${ }^{3} \mathrm{CV}(\%)$ & - & 09.2281 & 13.5214 & 09.1778 & 32.8107 \\
\hline
\end{tabular}

${ }^{1}$ SV: sources of variation; ${ }^{2} \mathrm{DF}$ : degrees of freedom; ${ }^{3} \mathrm{CV}$ : coefficient of variation; ${ }^{4} \mathrm{EPH}$ : efficiency of use of $A$. brasilense for plant height; ${ }^{5} \mathrm{EEH}$ : efficiency of use of $A$. brasilense for ear height; ${ }^{6} \mathrm{ERP}$ : efficiency of use of $A$. brasilense for relative ear position; ${ }^{7} \mathrm{EGY}$ : efficiency of use of $A$. brasilense for grain yield. ${ }^{\text {ns }}$, not significant by $\mathrm{F}$ test $(p>0.05)$.

Regarding the efficiency for plant height (EPH), the $\mathrm{t}$ test showed that 120 treatments were not significant. In other words, their values did not differ from 1 , which points to efficiency for that trait in these genotypes. The other 12 treatments showed signific- ance, differing from 1 at $5 \%$ significance. These treatments had higher mean efficiency values, being thus inefficient for the use of Azospirillum brasilense for the trait. For parameter 0 , all genotypes showed significant results at $1 \%$ significance (Table 2 ).

Table 2 - Number of efficient genotypes for the use of Azospirillum brasilense for plant height, ear height, relative position of the ear and grain yield, using Student's t test, in 132 maize genotypes, using 0 and 1 as comparative parameters.

\begin{tabular}{cccccccccccc}
\hline${ }^{1} \mathrm{EPH}$ & 0 & 1 & ${ }^{2} \mathrm{EEH}$ & 0 & 1 & ${ }^{3} \mathrm{ERP}$ & 0 & 1 & ${ }^{4} \mathrm{EGY}$ & 0 & 1 \\
\hline 120 & $* *$ & $\mathrm{~ns}$ & 127 & ${ }^{*}$ & $\mathrm{~ns}$ & 132 & $* *$ & $\mathrm{~ns}$ & 012 & $\mathrm{~ns}$ & $\mathrm{~ns}$ \\
012 & $* *$ & $*$ & 005 & $* *$ & $*$ & - & - & - & 044 & $*$ & $\mathrm{~ns}$ \\
- & - & - & - & - & - & - & - & - & 054 & $* *$ & ns \\
- & - & - & - & - & - & - & - & - & 019 & $* *$ & $*$ \\
- & - & - & - & - & - & - & - & - & 003 & $* *$ & $* *$ \\
\hline
\end{tabular}

${ }^{1} \mathrm{EPH}$ : efficiency of use of $A$. brasilense for plant height; ${ }^{2} \mathrm{EEH}$ : efficiency of use of $A$. brasilense for ear height; ${ }^{3} \mathrm{ERP}$ : efficiency of use of $A$. brasilense for relative ear position; ${ }^{4} \mathrm{EGY}$ : efficiency of use of $A$. brasilense for grain yield. By $\mathrm{t}$ test: ${ }^{* *}$ significant to $1 \%$ probability, ${ }^{*}$ significant to $5 \%$ of probability, ${ }^{\text {ns }}$ not significant

Regarding the efficiency for ear height $(\mathrm{EEH})$, 127 genotypes were not significant, not differing from parameter 1 and therefore showing efficiency for the trait. The other 5 treatments differed from 1 at $5 \%$ significance, being higher than 1 and indicating inefficiency for the trait. For parameter 0, all genotypes showed a significant difference at $1 \%$ significance (Table 2).

Regarding ERP, all genotypes were not significant, not differing from parameter 1 and showing efficiency for the trait. Parameter 0 reaffirmed these results for all genotypes, at $1 \%$ significance (Table 2).

For EGY, 110 genotypes were not significant, not differing from parameter 1 and thus being efficient for the use of Azospirillum brasilense. The other 22 genotypes differed from parameter 1 , with 3 of them $(54$, 60 , and 108 ) at $1 \%$ significance, corresponding to the highest values. Parameter 0 showed 120 genotypes with significant differences, 76 at $1 \%$ significance and 44 at $5 \%$ significance. The other 12 genotypes $(6,11,15$, $17,31,56,92,102,103,105,118$, and 121) did not show significance for parameters 0 and 1 simultaneously (Table 2).

The genotypes that did not show a significant difference in both parameters are those with lower mean values for EGY, indicating good yield in experiment 1 with Azospirillum brasilense. This confirms the efficiency of these genotypes for that trait (Table 3). The use of $A$. brasilense in maize favors the production of phytohormones that stimulate root growth. This improves plant nutrition and photosynthetic activities, increasing chlorophyll content, biomass production, and plant height (Hungria, 2011; Buzinaro et al., 2018; Revolti et al., 2018). 
Table 3 - Student's $\mathrm{t}$ test of the efficiency of use of Azospirillum brasilense for relative position of the ear and grain yield in 132 maize genotypes.

\begin{tabular}{|c|c|c|c|c|c|c|c|c|c|c|c|c|c|c|c|}
\hline${ }^{1} \mathrm{G}$ & ${ }^{2} \mathrm{C}$ & ${ }^{3} \mathrm{ERP}$ & 0 & 1 & ${ }^{4} \mathrm{EGY}$ & 0 & 1 & ${ }^{1} \mathrm{G}$ & ${ }^{2} \mathrm{C}$ & ${ }^{3} \mathrm{ERP}$ & 0 & 1 & ${ }^{4} \mathrm{EGY}$ & 0 & 1 \\
\hline$\overline{001}$ & $01 \times 02$ & 1.141 & ** & ns & 1.685 & * & ns & 067 & $02 \times 01$ & 1.105 & ** & $\mathrm{ns}$ & 2.255 & ** & ns \\
\hline 002 & $01 \times 03$ & 1.098 & ** & ns & 2.020 & ** & ns & 068 & $03 \times 01$ & 0.924 & ** & ns & 2.257 & ** & ns \\
\hline 003 & $01 \times 04$ & 1.054 & ** & ns & 1.920 & ** & ns & 069 & $04 \times 01$ & 1.037 & ** & ns & 1.995 & ** & ns \\
\hline 004 & $01 \times 05$ & 1.102 & ** & ns & 2.672 & ** & * & 070 & $05 \times 01$ & 1.051 & ** & ns & 2.287 & ** & ns \\
\hline 005 & $01 \times 06$ & 0.930 & ** & ns & 1.681 & * & ns & 071 & $06 \times 01$ & 1.064 & ** & ns & 1.932 & ** & ns \\
\hline 006 & $01 \times 07$ & 0.942 & ** & ns & 1.094 & ns & ns & 072 & $07 \times 01$ & 0.980 & ** & ns & 1.860 & ** & ns \\
\hline 007 & $01 \times 08$ & 1.004 & ** & ns & 1.834 & ** & ns & 073 & $08 \times 01$ & 1.037 & ** & ns & 1.814 & ** & ns \\
\hline 008 & $01 \times 09$ & 1.128 & ** & ns & 1.354 & * & ns & 074 & $09 \times 01$ & 1.023 & ** & ns & 1.718 & * & ns \\
\hline 009 & $01 \times 10$ & 1.026 & ** & ns & 1.927 & ** & ns & 075 & $10 \times 01$ & 0.989 & ** & $\mathrm{ns}$ & 2.089 & ** & ns \\
\hline 010 & $01 \times 11$ & 1.047 & ** & ns & 1.910 & ** & ns & 076 & $11 \times 01$ & 0.989 & ** & ns & 2.178 & ** & ns \\
\hline 011 & $01 \times 12$ & 0.954 & ** & ns & 1.288 & ns & ns & 077 & $12 \times 01$ & 1.034 & ** & ns & 1.511 & * & ns \\
\hline 012 & $02 \times 03$ & 1.022 & ** & ns & 1.866 & ** & ns & 078 & $03 \times 02$ & 1.049 & ** & ns & 2.007 & ** & ns \\
\hline 013 & $02 \times 04$ & 0.994 & ** & ns & 2.578 & ** & * & 079 & $04 \times 02$ & 1.055 & ** & ns & 2.006 & ** & ns \\
\hline 014 & $02 \times 05$ & 0.901 & ** & ns & 1.358 & * & ns & 080 & $05 \times 02$ & 1.023 & ** & ns & 2.365 & ** & * \\
\hline 015 & $02 \times 06$ & 1.043 & ** & ns & 1.280 & ns & ns & 081 & $06 \times 02$ & 1.032 & ** & ns & 2.012 & ** & ns \\
\hline 016 & $02 \times 07$ & 1.072 & ** & ns & 1.721 & * & ns & 082 & $07 \times 02$ & 0.968 & ** & ns & 2.012 & ** & ns \\
\hline 017 & $02 \times 08$ & 1.091 & ** & ns & 1.275 & ns & ns & 083 & $08 \times 02$ & 1.035 & ** & ns & 1.684 & * & ns \\
\hline 018 & $02 \times 09$ & 1.023 & ** & ns & 2.506 & ** & * & 084 & $09 \times 02$ & 0.930 & ** & ns & 1.554 & * & ns \\
\hline 019 & $02 \times 10$ & 1.054 & ** & ns & 2.526 & ** & * & 085 & $10 \times 02$ & 1.002 & ** & ns & 1.843 & ** & ns \\
\hline 020 & $02 \times 11$ & 1.050 & ** & ns & 2.382 & ** & * & 086 & $11 \times 02$ & 1.010 & ** & ns & 2.034 & ** & ns \\
\hline 021 & $02 \times 12$ & 1.053 & ** & ns & 2.365 & ** & * & 087 & $12 \times 02$ & 1.007 & ** & ns & 1.676 & * & ns \\
\hline 022 & $03 \times 04$ & 0.935 & ** & ns & 2.073 & ** & ns & 088 & $04 \times 03$ & 1.090 & ** & ns & 1.521 & * & ns \\
\hline 023 & $03 \times 05$ & 0.976 & ** & ns & 1.369 & * & ns & 089 & $05 \times 03$ & 1.000 & ** & ns & 1.395 & * & ns \\
\hline 024 & $03 \times 06$ & 1.010 & ** & ns & 1.388 & * & ns & 090 & $06 \times 03$ & 0.985 & ** & ns & 1.603 & * & ns \\
\hline 025 & $03 \times 07$ & 0.908 & ** & ns & 2.039 & ** & ns & 091 & $07 \times 03$ & 1.032 & ** & ns & 1.577 & * & ns \\
\hline 026 & $03 \times 08$ & 1.051 & ** & ns & 1.737 & * & ns & 092 & $08 \times 03$ & 1.006 & ** & ns & 1.171 & ns & ns \\
\hline 027 & $03 \times 09$ & 1.017 & ** & ns & 2.720 & ** & * & 093 & $09 \times 03$ & 1.055 & ** & $\mathrm{ns}$ & 1.698 & * & ns \\
\hline 028 & $03 \times 10$ & 0.964 & ** & ns & 2.148 & ** & ns & 094 & $10 \times 03$ & 0.996 & ** & ns & 1.491 & * & ns \\
\hline 029 & $03 \times 11$ & 0.947 & ** & ns & 1.311 & * & ns & 095 & $11 \times 03$ & 1.016 & ** & ns & 1.434 & * & ns \\
\hline 030 & $03 \times 12$ & 1.056 & ** & ns & 1.347 & * & ns & 096 & $12 \times 03$ & 0.882 & ** & ns & 1.363 & * & ns \\
\hline 031 & $04 \times 05$ & 1.024 & ** & ns & 1.219 & ns & ns & 097 & $05 \times 04$ & 1.026 & ** & ns & 2.341 & ** & * \\
\hline 032 & $04 \times 06$ & 0.952 & ** & ns & 1.382 & * & ns & 098 & $06 \times 04$ & 0.991 & ** & ns & 1.642 & * & ns \\
\hline 033 & $04 \times 07$ & 1.065 & ** & ns & 2.333 & ** & * & 099 & $07 \times 04$ & 1.001 & ** & ns & 1.388 & * & ns \\
\hline 034 & $04 \times 08$ & 0.999 & ** & ns & 1.998 & ** & ns & 100 & $08 \times 04$ & 1.053 & ** & ns & 2.228 & ** & ns \\
\hline 035 & $04 \times 09$ & 0.988 & ** & ns & 2.008 & ** & ns & 101 & $09 \times 04$ & 1.028 & ** & $\mathrm{ns}$ & 1.645 & * & ns \\
\hline 036 & $04 \times 10$ & 1.034 & ** & ns & 1.612 & * & ns & 102 & $10 \times 04$ & 1.003 & ** & ns & 1.294 & ns & ns \\
\hline 037 & $04 \times 11$ & 0.958 & ** & ns & 1.340 & * & ns & 103 & $11 \times 04$ & 1.022 & ** & ns & 1.233 & ns & ns \\
\hline 038 & $04 \times 12$ & 1.043 & ** & ns & 1.897 & ** & ns & 104 & $12 \times 04$ & 1.015 & ** & ns & 2.240 & ** & ns \\
\hline 039 & $05 \times 06$ & 0.910 & ** & ns & 2.471 & ** & * & 105 & $06 \times 05$ & 1.049 & ** & $\mathrm{ns}$ & 1.261 & ns & ns \\
\hline 040 & $05 \times 07$ & 1.064 & ** & ns & 2.050 & ** & ns & 106 & $07 \times 05$ & 1.088 & ** & $\mathrm{ns}$ & 1.957 & ** & ns \\
\hline 041 & $05 \times 08$ & 0.985 & ** & ns & 1.712 & * & ns & 107 & $08 \times 05$ & 1.036 & ** & ns & 1.933 & ** & ns \\
\hline 042 & $05 \times 09$ & 0.981 & ** & ns & 1.501 & * & ns & 108 & $09 \times 05$ & 0.971 & ** & ns & 2.996 & ** & ** \\
\hline 043 & $05 \times 10$ & 0.896 & ** & ns & 1.636 & * & ns & 109 & $10 \times 05$ & 1.049 & ** & ns & 2.162 & ** & ns \\
\hline 044 & $05 \times 11$ & 1.053 & ** & ns & 1.927 & ** & ns & 110 & $11 \times 05$ & 0.904 & ** & ns & 2.263 & ** & ns \\
\hline 045 & $05 \times 12$ & 0.924 & ** & ns & 2.007 & ** & ns & 111 & $12 \times 05$ & 0.953 & ** & $\mathrm{ns}$ & 2.175 & ** & ns \\
\hline 046 & $06 \times 07$ & 0.991 & ** & ns & 1.705 & * & ns & 112 & $07 \times 06$ & 1.072 & ** & ns & 2.519 & ** & * \\
\hline 047 & $06 \times 08$ & 0.949 & ** & ns & 2.470 & ** & * & 113 & $08 \times 06$ & 1.065 & ** & ns & 1.918 & ** & ns \\
\hline 048 & $06 \times 09$ & 1.030 & ** & ns & 1.682 & * & ns & 114 & $09 \times 06$ & 1.127 & ** & ns & 2.271 & ** & ns \\
\hline 049 & $06 \times 10$ & 0.996 & ** & ns & 2.631 & ** & * & 115 & $10 \times 06$ & 0.825 & ** & ns & 1.781 & ** & ns \\
\hline 050 & $06 \times 11$ & 1.026 & ** & ns & 1.407 & * & ns & 116 & $11 \times 06$ & 1.001 & ** & ns & 1.954 & ** & ns \\
\hline 051 & $06 \times 12$ & 0.942 & ** & ns & 2.404 & ** & * & 117 & $12 \times 06$ & 1.106 & ** & ns & 2.055 & ** & ns \\
\hline 052 & $07 \times 08$ & 1.051 & ** & ns & 2.032 & ** & ns & 118 & $08 \times 07$ & 1.066 & ** & ns & 1.235 & ns & ns \\
\hline 053 & $07 \times 09$ & 1.005 & ** & ns & 1.357 & * & ns & 119 & $09 \times 07$ & 1.043 & ** & ns & 1.654 & * & ns \\
\hline 054 & $07 \times 10$ & 1.112 & ** & ns & 2.861 & ** & ** & 120 & $10 \times 07$ & 1.046 & ** & ns & 2.264 & ** & ns \\
\hline 055 & $07 \times 11$ & 1.032 & ** & ns & 2.495 & ** & * & 121 & $11 \times 07$ & 0.988 & ** & ns & 1.035 & ns & ns \\
\hline 056 & $07 \times 12$ & 0.999 & ** & ns & 1.239 & ns & ns & 122 & $12 \times 07$ & 0.977 & ** & ns & 1.466 & * & ns \\
\hline
\end{tabular}


Table 3 - Cont...

\begin{tabular}{lccccccccccccccc}
\hline $1 \mathrm{G}$ & ${ }^{2} \mathrm{C}$ & ${ }^{3} \mathrm{ERP}$ & 0 & 1 & $4 \mathrm{EGY}$ & 0 & 1 & ${ }^{1} \mathrm{G}$ & ${ }^{2} \mathrm{C}$ & ${ }^{3} \mathrm{ERP}$ & 0 & 1 & $4 \mathrm{EGY}$ & 0 & 1 \\
\hline 057 & $08 \times 09$ & 0.969 & $* *$ & $\mathrm{~ns}$ & 1.867 & $* *$ & $\mathrm{~ns}$ & 123 & $09 \times 08$ & 1.006 & $* *$ & $\mathrm{~ns}$ & 2.314 & $* *$ & $*$ \\
058 & $08 \times 10$ & 1.049 & $* *$ & $\mathrm{~ns}$ & 2.160 & $* *$ & $\mathrm{~ns}$ & 124 & $10 \times 08$ & 1.046 & $* *$ & $\mathrm{~ns}$ & 1.695 & $*$ & $\mathrm{~ns}$ \\
059 & $08 \times 11$ & 1.021 & $* *$ & $\mathrm{~ns}$ & 2.638 & $* *$ & $*$ & 125 & $11 \times 08$ & 1.103 & $* *$ & $\mathrm{~ns}$ & 1.793 & $* *$ & $\mathrm{~ns}$ \\
060 & $08 \times 12$ & 1.001 & $* *$ & $\mathrm{~ns}$ & 2.777 & $* *$ & $* *$ & 126 & $12 \times 08$ & 1.134 & $* *$ & $\mathrm{~ns}$ & 1.871 & $* *$ & $\mathrm{~ns}$ \\
061 & $09 \times 10$ & 0.975 & $* *$ & $\mathrm{~ns}$ & 1.815 & $* *$ & $\mathrm{~ns}$ & 127 & $10 \times 09$ & 1.040 & $* *$ & $\mathrm{~ns}$ & 2.057 & $* *$ & $\mathrm{~ns}$ \\
062 & $09 \times 11$ & 0.990 & $* *$ & $\mathrm{~ns}$ & 1.999 & $* *$ & $\mathrm{~ns}$ & 128 & $11 \times 09$ & 1.139 & $* *$ & $\mathrm{~ns}$ & 1.996 & $* *$ & $\mathrm{~ns}$ \\
063 & $09 \times 12$ & 1.133 & $* *$ & $\mathrm{~ns}$ & 1.646 & $*$ & $\mathrm{~ns}$ & 129 & $12 \times 09$ & 1.162 & $* *$ & $\mathrm{~ns}$ & 1.670 & $*$ & $\mathrm{~ns}$ \\
064 & $10 \times 11$ & 1.012 & $* *$ & $\mathrm{~ns}$ & 1.920 & $* *$ & $\mathrm{~ns}$ & 130 & $11 \times 10$ & 0.843 & $* *$ & $\mathrm{~ns}$ & 1.412 & $*$ & $\mathrm{~ns}$ \\
065 & $10 \times 12$ & 1.060 & $* *$ & $\mathrm{~ns}$ & 2.511 & $* *$ & $*$ & 131 & $12 \times 10$ & 0.983 & $* *$ & $\mathrm{~ns}$ & 1.436 & $*$ & $\mathrm{~ns}$ \\
066 & $11 \times 12$ & 1.112 & $* *$ & $\mathrm{~ns}$ & 1.678 & $*$ & $\mathrm{~ns}$ & 132 & $12 \times 11$ & 1.013 & $* *$ & $\mathrm{~ns}$ & 2.070 & $* *$ & $\mathrm{~ns}$ \\
\hline
\end{tabular}

${ }^{1} \mathrm{G}$ : Genotype; ${ }^{2} \mathrm{C}$ : Crossing; ${ }^{3} \mathrm{ERP}$ : efficiency of use of $A$. brasilense for relative ear position; ${ }^{4} \mathrm{EGY}$ : efficiency of use of $A$. brasilense for grain yield. By t test: ${ }^{* *}$ significant to $1 \%$ probability, ${ }^{*}$ significant to $5 \%$ of probability, ${ }^{\text {ns }}$ not significant

Pereira \& Tozoni (2017) used a maize hybrid that showed higher grain yield in the treatment with Azospirillum inoculation. This increase, however, only occurred when the treatment included nitrogen fertilization. Several studies addressing the response of maize genotypes to inoculation with Azospirillum brasilense have identified that genotypes interact with the microorganism (Pereira et al., 2015). This differential response of the genotypes also occurs in their response to nitrogen (Han et al., 2015; Amaral et al., 2018).

In general, one can infer that genotypes that are more responsive to Azospirillum brasilense favor nutrient use efficiency, which is positive for trait enhancement through genetic breeding programs.

The experiment by Pereira \& Tozoni (2017) indicates favorable results depending on the affinity of the cultivar with the microorganism strain. This corroborates Hungria (2011) and other authors who observed functional nitrogenase activity depending on the bacterial strain and the genetic material of maize (Brusamello-Santos et al., 2017; Pereira-Defilippi et al., 2017; Buzinaro et al., 2018; Revolti et al., 2018).

In the diallel analysis, the results of the Griffing test (1956) for general combining ability (GCA), specific combining ability (SCA), and reciprocal effects (RE) did not differ among themselves for the 132 genotypes, for all traits. As the reciprocal effects were not significant, it appears that there is no maternal inheritance for efficiency regarding these traits and, therefore, the genes that affect them are probably nuclear (Cruz \& Regazzi, 2014) (Table 4).

Table 4 - Summary of diallel analyzes of the efficiency of use of Azospirillum brasilense for plant height, ear height, relative ear position and grain yield of 132 maize genotypes.

\begin{tabular}{lccccc}
\hline \multirow{2}{*}{${ }^{1} S V$} & \multirow{2}{*}{$\mathrm{DF}$} & \multicolumn{4}{c}{ Mean squares } \\
\cline { 3 - 6 } & & ${ }^{5} \mathrm{EPH}$ & ${ }^{6} \mathrm{EEH}$ & ${ }^{7} \mathrm{ERP}$ & ${ }^{8} E G Y$ \\
\hline Treatment & 131 & $0.0212^{\text {ns }}$ & $0.0495^{\text {ns }}$ & $0.0163 \mathrm{~ns}$ & $1.0964^{\text {ns }}$ \\
${ }^{3} \mathrm{GCA}$ & 11 & $0.0266^{\text {ns }}$ & $0.0595^{\text {ns }}$ & $0.0189 \mathrm{~ns}$ & $0.9028^{\text {ns }}$ \\
${ }^{4} \mathrm{SCA}$ & 54 & $0.0242^{\text {ns }}$ & $0.0528^{\text {ns }}$ & $0.0161 \mathrm{~ns}$ & $1.1605^{\text {ns }}$ \\
Reciprocal & 66 & $0.0178^{\text {ns }}$ & $0.0451^{\text {ns }}$ & $0.0160 \mathrm{~ns}$ & $1.0763^{\text {ns }}$ \\
Error & 131 & 1.0000 & 1.0000 & 1.0000 & 1.0000 \\
Total & 393 & - & - & - & - \\
\hline Mean & - & 1.1359 & 1.1655 & 1.0246 & 2.2071
\end{tabular}

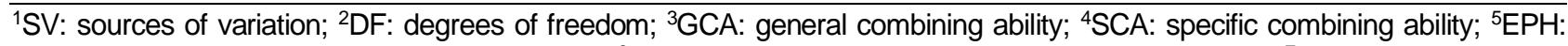
efficiency of use of $A$. brasilense for plant height; ${ }^{6} \mathrm{EEH}$ : efficiency of use of $A$. brasilense for ear height; ${ }^{7} \mathrm{ERP}$ : efficiency of use of $A$. brasilense for relative ear position; ${ }^{8} \mathrm{EGY}$ : efficiency of use of $A$. brasilense for grain yield. ${ }^{\text {ns }}$ not significant by $\mathrm{F}$ test $(\mathrm{p}>$ $0.05)$

Also in the diallel analysis, the quadratic components of GCA and SCA indicate the type of gene effect favored by gene actions, for each trait (Griffing, 1956; Cruz \& Regazzi, 2014). A higher value for the quadratic components of GCA in relation to those of SCA favors the occurrence of additive gene effects. In turn, a higher value for the quadratic components of SCA in relation to those of GCA favor nonadditive gene effects (Ferreira et al., 2002). Quadratic values differed from zero only in EGY, with SCA being higher than GCA, thus favoring nonadditive gene effects (Table 5). 
Table 5 - Quadratic components of the combining capabilities for the efficiency of use of Azospirillum brasilense of plant height, ear height, relative position of the ear and grain yield of 132 maize genotypes.

\begin{tabular}{lcccc}
\hline \multirow{2}{*}{ Components } & \multicolumn{4}{c}{ Fixed model } \\
\cline { 2 - 5 } & ${ }^{3} \mathrm{EPH}$ & ${ }^{4} \mathrm{EEH}$ & ${ }^{5} \mathrm{ERP}$ & ${ }^{6} \mathrm{EGY}$ \\
\hline${ }^{1} \mathrm{GCA}$ & 0 & 0 & 0 & 0 \\
${ }^{2} \mathrm{SCA}$ & 0 & 0 & 0 & 0.0401 \\
\hline
\end{tabular}

${ }^{1} \mathrm{GCA}$ : general combining ability; ${ }^{2} \mathrm{SCA}$ : specific combining ability; ${ }^{3} \mathrm{EPH}$ : efficiency of use of $A$. brasilense for plant height; ${ }^{4} \mathrm{EEH}$ : efficiency of use of $A$. brasilense for ear height; ${ }^{5} \mathrm{ERP}$ : efficiency of use of $A$. brasilense for relative ear position; ${ }^{6} \mathrm{EGY}$ : efficiency of use of $A$. brasilense for grain yield.

The estimates of the GCA effects of parents did not differ for the traits under study (Table 6), with values very close to zero. The minimum and maximum values were, respectively: -0.0448 (parent 10) and 0.0395 (parent 01) for $\mathrm{EPH} ;-0.056$ (parent 10) and 0.0507 (parent 09) for EEH; -0.0433 (parent 03) and 0.0367 (parent 09) for ERP; -0.2718 (parent 11) and 0.1751 (parent 05) for EGY. The largest interval between the minimum and maximum values occurred for EGY, corresponding to 0.447 .

Table 6 - Estimation of the effects of the general combining ability regarding the efficient use of Azospirillum brasilense for plant height, ear height, relative ear position and grain yield for 12 maize parents.

\begin{tabular}{ccccc}
\hline \multirow{2}{*}{ Parents } & \multicolumn{3}{c}{${ }^{1} \mathrm{GCA}$} \\
\cline { 2 - 5 } & ${ }^{2} \mathrm{EPH}$ & ${ }^{3} \mathrm{EEH}$ & ${ }^{4} \mathrm{ERP}$ & ${ }^{5} \mathrm{EGY}$ \\
\hline 01 & 0.0395 & 0.0499 & 0.0086 & 0.0172 \\
02 & 0.0183 & 0.0417 & 0.0195 & 0.1470 \\
03 & -0.0047 & -0.0550 & -0.0433 & -0.2377 \\
04 & -0.0329 & -0.0306 & 0.0053 & -0.1079 \\
05 & 0.0029 & -0.0151 & -0.0181 & 0.1751 \\
06 & -0.0244 & -0.0330 & -0.0068 & 0.0893 \\
07 & 0.0373 & 0.0265 & -0.0106 & -0.0428 \\
08 & -0.0120 & 0.0206 & 0.0291 & 0.1700 \\
09 & 0.0096 & 0.0507 & 0.0367 & 0.0079 \\
10 & -0.0448 & -0.0560 & -0.0083 & 0.1085 \\
11 & 0.0061 & -0.0012 & -0.0070 & -0.2718 \\
12 & 0.0051 & 0.0014 & 0.0051 & -0.0550 \\
\hline $\mathrm{SD}(\mathrm{Gi})$ & 0.1513 & 0.1513 & 0.1513 & 0.1513 \\
$\mathrm{SD}(\mathrm{Gi}-\mathrm{Gj})$ & 0.2236 & 0.2236 & 0.2236 & 0.2236 \\
\hline
\end{tabular}

${ }^{1} \mathrm{GCA}$ : general combining ability; ${ }^{2} \mathrm{EPH}$ : efficiency of use of $A$. brasilense for plant height; ${ }^{3} \mathrm{EEH}$ : efficiency of use of A. brasilense for ear height; ${ }^{4} \mathrm{ERP}$ : efficiency of use of $A$. brasilense for relative ear position; ${ }^{5} \mathrm{EGY}$ : efficiency of use of A. brasilense for grain yield; ${ }^{6} \mathrm{SD}$ : standard deviation

According to Cruz \& Regazzi (2014), more extreme GCA values indicate whether the parent will have more or less favorable alleles. Results close to zero indicate nondifferential behavior in relation to the general mean of the parents, meaning that these parents do not stand out positively or negatively with regard to the number of favorable alleles. Depending on the trait, extreme positive values represent a greater number of favorable alleles. This occurred for all traits under study.

Among the 12 parents, 7 showed positive values and 5 showed negative values for EPH. For EEH and ERP, 6 parents showed positive values and 6 showed negative values. For EGY, 7 parents showed positive values and 5 showed negative values.

The SCA effects for crosses and reciprocals did not differ for the traits under study (Tables 7 and 8). For these effects, which refer to nonadditive gene effects, nonsignificance of the traits prevents the determination of superior combinations of parents according to their mean. In Tables 7 and 8, the minimum and maximum values of the crosses were, respectively: -0.1402 (cross

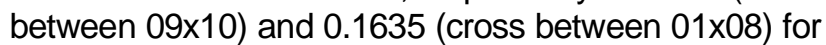
$\mathrm{EPH}$; -0.2025 (01X07) and 0.3011 (06×11) for $\mathrm{EEH}$; $0.1196(01 \times 07)$ and 0.1681 (09x12) for ERP; -1.1005 $(03 \times 05)$ and $1.3465(05 \times 07)$ for EGY. The largest range of SCA occurred for EGY and had a very low value, 2.4471 . 
Table 7 - Estimates of the effects of the specific combining ability and the reciprocal effect, regarding the efficiency of use of Azospirillum brasilense for plant height and ear height for 12 parents in maize.

\begin{tabular}{|c|c|c|c|c|}
\hline \multirow{2}{*}{ Crossing } & \multicolumn{2}{|c|}{${ }^{2} \mathrm{EPH}$} & \multicolumn{2}{|c|}{${ }^{3} \mathrm{EEH}$} \\
\hline & ${ }^{1} \mathrm{SCA}$ & Reciprocal & ${ }^{1} \mathrm{SCA}$ & Reciprocal \\
\hline $01 \times 02$ & 0.0186 & 0.0395 & 0.0937 & 0.0090 \\
\hline $01 \times 03$ & 0.0162 & -0.1020 & -0.0299 & 0.0215 \\
\hline $01 \times 04$ & 0.0114 & -0.0280 & 0.0325 & -0.0025 \\
\hline $01 \times 05$ & 0.1000 & 0.0485 & 0.2206 & 0.1260 \\
\hline $01 \times 06$ & -0.0815 & -0.0175 & -0.1015 & -0.0520 \\
\hline $01 \times 07$ & -0.0623 & -0.0235 & -0.2025 & -0.0535 \\
\hline $01 \times 08$ & 0.1635 & -0.0120 & 0.1673 & -0.0295 \\
\hline $01 \times 09$ & -0.1011 & 0.1420 & 0.0112 & 0.2105 \\
\hline $01 \times 10$ & 0.0088 & 0.0345 & -0.0060 & 0.0045 \\
\hline $01 \times 11$ & -0.1021 & -0.0285 & -0.1462 & -0.0670 \\
\hline $01 \times 12$ & 0.0283 & 0.0110 & -0.0389 & -0.0040 \\
\hline $02 \times 03$ & -0.1080 & 0.0885 & -0.0002 & 0.1820 \\
\hline $02 \times 04$ & -0.0333 & 0.0450 & -0.0542 & 0.0555 \\
\hline $02 \times 05$ & 0.0062 & -0.1115 & -0.0951 & -0.1530 \\
\hline $02 \times 06$ & 0.1181 & 0.0850 & 0.1401 & 0.1085 \\
\hline $02 \times 07$ & 0.0328 & -0.0485 & 0.0496 & -0.0285 \\
\hline $02 \times 08$ & -0.0482 & 0.0360 & -0.0719 & 0.1000 \\
\hline $02 \times 09$ & -0.0239 & -0.0520 & -0.1135 & -0.0145 \\
\hline $02 \times 10$ & 0.0895 & 0.1260 & 0.0716 & 0.1150 \\
\hline $02 \times 11$ & 0.0225 & -0.0330 & 0.0404 & 0.0875 \\
\hline $02 \times 12$ & -0.0744 & 0.2250 & -0.0602 & 0.2975 \\
\hline $03 \times 04$ & -0.0432 & 0.0960 & -0.0214 & 0.0745 \\
\hline $03 \times 05$ & 0.0509 & 0.0480 & 0.0421 & 0.0105 \\
\hline $03 \times 06$ & -0.0102 & -0.0155 & -0.0980 & -0.0215 \\
\hline $03 \times 07$ & -0.0644 & -0.0670 & -0.1010 & -0.1820 \\
\hline $03 \times 08$ & 0.0208 & 0.0100 & 0.0518 & 0.0780 \\
\hline $03 \times 09$ & 0.0871 & 0.0530 & 0.1937 & 0.0830 \\
\hline $03 \times 10$ & -0.0168 & 0.0325 & -0.0075 & 0.0320 \\
\hline $03 \times 11$ & 0.0271 & 0.0155 & 0.0247 & -0.0130 \\
\hline $03 \times 12$ & 0.0402 & 0.0235 & -0.0539 & 0.1310 \\
\hline $04 \times 05$ & -0.1279 & 0.0350 & -0.1378 & 0.0380 \\
\hline $04 \times 06$ & 0.0564 & 0.1070 & 0.0245 & -0.0135 \\
\hline $04 \times 07$ & -0.0473 & -0.0640 & -0.0290 & -0.0385 \\
\hline $04 \times 08$ & -0.0404 & -0.0075 & -0.0495 & -0.0780 \\
\hline $04 \times 09$ & 0.0588 & 0.0315 & -0.0127 & -0.0470 \\
\hline $04 \times 10$ & 0.0733 & -0.0155 & 0.1090 & 0.0210 \\
\hline $04 \times 11$ & 0.0748 & -0.0440 & 0.0722 & -0.0440 \\
\hline $04 \times 12$ & 0.0173 & 0.0595 & 0.0665 & 0.0720 \\
\hline $05 \times 06$ & -0.0679 & -0.0895 & -0.0314 & -0.0750 \\
\hline $05 \times 07$ & 0.0503 & 0.0125 & 0.1830 & -0.0880 \\
\hline $05 \times 08$ & -0.0503 & 0.0665 & -0.0665 & 0.0895 \\
\hline $05 \times 09$ & 0.0644 & 0.1410 & -0.0186 & 0.1855 \\
\hline $05 \times 10$ & 0.0509 & -0.0340 & -0.0144 & -0.2210 \\
\hline $05 \times 11$ & 0.0419 & 0.0160 & 0.0938 & 0.0760 \\
\hline $05 \times 12$ & -0.1189 & -0.0400 & -0.1753 & -0.0435 \\
\hline $06 \times 07$ & 0.1141 & -0.1250 & 0.0363 & -0.2645 \\
\hline $06 \times 08$ & -0.1274 & -0.0420 & -0.1531 & -0.0940 \\
\hline $06 \times 09$ & -0.0436 & 0.1555 & 0.0046 & 0.1460 \\
\hline $06 \times 10$ & -0.0841 & 0.0155 & -0.0750 & -0.0055 \\
\hline $06 \times 11$ & 0.1473 & 0.0410 & 0.3011 & 0.0155 \\
\hline $06 \times 12$ & -0.0211 & -0.0165 & -0.0475 & -0.1485 \\
\hline $07 \times 08$ & 0.0197 & 0.0200 & 0.0432 & 0.0420 \\
\hline $07 \times 09$ & 0.0365 & 0.0025 & 0.0456 & -0.0225 \\
\hline $07 \times 10$ & -0.0374 & 0.0120 & 0.0738 & 0.0620 \\
\hline $07 \times 11$ & 0.0040 & 0.0785 & 0.0081 & 0.0290 \\
\hline
\end{tabular}


Table 7 - Cont...

\begin{tabular}{|c|c|c|c|c|}
\hline \multirow{2}{*}{ Crossing } & \multicolumn{2}{|c|}{${ }^{2} \mathrm{EPH}$} & \multicolumn{2}{|c|}{${ }^{3} \mathrm{EEH}$} \\
\hline & ${ }^{1} \mathrm{SCA}$ & Reciprocal & ${ }^{1}$ SCA & Reciprocal \\
\hline $07 \times 12$ & -0.0463 & 0.0320 & -0.1070 & 0.0935 \\
\hline $08 \times 09$ & 0.0789 & 0.0805 & -0.0084 & 0.0415 \\
\hline $08 \times 10$ & 0.0269 & -0.0550 & 0.0708 & -0.0640 \\
\hline $08 \times 11$ & -0.1030 & -0.0310 & -0.0884 & -0.1555 \\
\hline $08 \times 12$ & 0.0594 & -0.0405 & 0.1048 & -0.1265 \\
\hline $09 \times 10$ & -0.1402 & -0.0255 & -0.1658 & -0.1025 \\
\hline $09 \times 11$ & -0.0357 & -0.0290 & -0.1550 & 0.0480 \\
\hline $09 \times 12$ & 0.0187 & -0.0655 & 0.2192 & -0.1640 \\
\hline $10 \times 11$ & -0.0722 & -0.0040 & -0.1498 & 0.2255 \\
\hline $10 \times 12$ & 0.1012 & 0.0025 & 0.0934 & 0.0625 \\
\hline $11 \times 12$ & -0.0047 & -0.0545 & -0.0007 & -0.0290 \\
\hline $\mathrm{SD}^{4}(\mathrm{Sij})$ & 0.4522 & - & 0.4522 & - \\
\hline SD(Sij-Sik) & 0.6708 & - & 0.6708 & - \\
\hline SD(Sij-Skl) & 0.6324 & - & 0.6324 & - \\
\hline SD(Rij) & - & 0.5000 & - & 0.5000 \\
\hline
\end{tabular}

${ }^{1}$ SCA: specific combining ability; ${ }^{2} \mathrm{EPH}$ : efficiency of use of $A$. brasilense for plant height; ${ }^{3} \mathrm{EEH}$ : efficiency of use of $A$. brasilense for ear height; ${ }^{4} \mathrm{SD}$ : standard deviation.

Among the 66 crosses, 36 showed positive values and 30 showed negative values for EPH. For $\mathrm{EEH}, 30$ crosses showed positive values and 36 showed negative values. For ERP, 32 crosses showed positive values and 34 showed negative values. For EGY, 33 crosses showed positive values and 33 showed negative values.

Table 8 - Estimates of the effects of the specific combining ability and the reciprocal effect, regarding the efficiency of use of Azospirillum brasilense for relative position of the ear and grain yield for the 12 maize parents.

\begin{tabular}{lrrrr}
\hline \multirow{2}{*}{ Crossing } & \multicolumn{2}{c}{${ }^{2}$ ERP } & ${ }^{3} E G Y$ & Reciprocal \\
\cline { 2 - 5 } & 1 SCA & -0.0295 & 0.2510 & -0.4725 \\
$01 \times 02$ & 0.0615 & 0.1005 & 0.1343 & -0.0630 \\
$01 \times 03$ & -0.0294 & 0.0235 & 0.2500 & 0.0925 \\
$01 \times 04$ & 0.0167 & 0.0565 & -0.0070 & 0.3815 \\
$01 \times 06$ & 0.0942 & -0.0320 & 0.0602 & -0.6300 \\
$01 \times 07$ & -0.0164 & -0.0280 & -0.6370 & -0.3975 \\
$01 \times 08$ & -0.1196 & -0.0130 & 0.2140 & 0.3835 \\
$01 \times 09$ & -0.0054 & 0.0400 & -0.7758 & -0.3505 \\
$01 \times 10$ & 0.1029 & -0.0260 & 0.3780 & -0.3330 \\
$01 \times 11$ & -0.0120 & -0.0360 & 0.3509 & 0.4965 \\
$01 \times 12$ & -0.0383 & -0.0120 & -0.2188 & -0.1235 \\
$02 \times 03$ & -0.0542 & 0.0815 & 0.3010 & 0.2085 \\
$02 \times 04$ & 0.0975 & 0.0080 & 0.7597 & 1.0170 \\
$02 \times 05$ & -0.0186 & -0.0415 & -0.6338 & -0.5205 \\
$02 \times 06$ & -0.0876 & 0.0150 & -0.5850 & -0.3575 \\
$02 \times 07$ & 0.0145 & 0.0185 & 0.1231 & -0.2125 \\
$02 \times 08$ & 0.0148 & 0.0570 & -0.6152 & -0.2060 \\
$02 \times 09$ & -0.0194 & 0.0330 & 0.0923 & 0.6075 \\
$02 \times 10$ & -0.0750 & -0.0110 & -0.1607 & 0.2060 \\
$02 \times 11$ & -0.0149 & 0.1035 & 0.6321 & 0.5215 \\
$02 \times 12$ & 0.0192 & 0.0570 & -0.1646 & 0.2805 \\
$03 \times 04$ & 0.0078 & -0.0210 & 0.2760 & 0.3855 \\
$03 \times 05$ & 0.0182 & -0.0300 & -1.1005 & 0.0270 \\
$03 \times 06$ & -0.0022 & -0.0070 & -0.2812 & -0.3735 \\
$03 \times 07$ & -0.0824 & -0.1085 & -0.1570 & 0.0045 \\
$03 \times 08$ & -0.0391 & 0.0595 & -0.2389 & 0.4565 \\
$03 \times 09$ & 0.0270 & 0.0200 & 0.9371 & 0.0835
\end{tabular}


Table 8 - Cont...

\begin{tabular}{|c|c|c|c|c|}
\hline \multirow{2}{*}{ Crossing } & \multicolumn{2}{|c|}{${ }^{2} \mathrm{ERP}$} & \multicolumn{2}{|c|}{${ }^{3} E G Y$} \\
\hline & ${ }^{1} \mathrm{SCA}$ & Reciprocal & ${ }^{1} \mathrm{SCA}$ & Reciprocal \\
\hline $03 \times 10$ & 0.0064 & 0.0005 & 0.5775 & 1.2905 \\
\hline $03 \times 11$ & -0.0008 & -0.0245 & -0.1945 & 0.1030 \\
\hline $03 \times 12$ & -0.0792 & 0.0930 & -0.2538 & -0.0965 \\
\hline $04 \times 05$ & -0.0084 & 0.0035 & -0.3923 & -0.1370 \\
\hline $04 \times 06$ & -0.0207 & -0.1065 & 0.1414 & -0.1320 \\
\hline $04 \times 07$ & 0.0180 & 0.0255 & 0.3411 & 0.4545 \\
\hline $04 \times 08$ & -0.0077 & -0.0665 & -0.0097 & -0.0315 \\
\hline $04 \times 09$ & -0.0638 & -0.0670 & 0.3098 & -0.0690 \\
\hline $04 \times 10$ & 0.0282 & 0.0330 & -0.8207 & 0.1320 \\
\hline $04 \times 11$ & -0.0055 & 0.0005 & -0.7713 & 0.2040 \\
\hline $04 \times 12$ & 0.0435 & 0.0075 & -0.0841 & 0.0340 \\
\hline $05 \times 06$ & 0.0392 & 0.0170 & 0.5863 & 2.1180 \\
\hline $05 \times 07$ & 0.1130 & -0.0830 & 1.3465 & -0.1430 \\
\hline $05 \times 08$ & -0.0112 & 0.0195 & -0.1798 & -0.6655 \\
\hline $05 \times 09$ & -0.0733 & 0.0400 & 0.1412 & -0.2325 \\
\hline $05 \times 10$ & -0.0602 & -0.1650 & -0.3248 & -0.2570 \\
\hline $05 \times 11$ & 0.0464 & 0.0500 & -0.0269 & -0.5745 \\
\hline $05 \times 12$ & -0.0499 & -0.0055 & 0.5912 & -0.5095 \\
\hline $06 \times 07$ & -0.0726 & -0.1165 & -0.1046 & -0.2860 \\
\hline $06 \times 08$ & -0.0204 & -0.0525 & 0.2704 & 0.9410 \\
\hline $06 \times 09$ & 0.0504 & -0.0240 & -0.0439 & 0.0445 \\
\hline $06 \times 10$ & 0.0094 & -0.0220 & 0.1239 & 0.1900 \\
\hline $06 \times 11$ & 0.1221 & -0.0240 & -0.4421 & -0.3195 \\
\hline $06 \times 12$ & -0.0232 & -0.1205 & 0.2745 & 0.2070 \\
\hline $07 \times 08$ & 0.0198 & 0.0180 & -0.0578 & 0.5755 \\
\hline $07 \times 09$ & 0.0057 & -0.0205 & -0.4772 & -0.2470 \\
\hline $07 \times 10$ & 0.1027 & 0.0445 & 0.3491 & 0.3170 \\
\hline $07 \times 11$ & 0.0084 & -0.0425 & -0.0374 & 0.3030 \\
\hline $07 \times 12$ & -0.0514 & 0.0555 & -0.6887 & 0.0695 \\
\hline $08 \times 09$ & -0.0755 & -0.0330 & 0.3229 & -0.6980 \\
\hline $08 \times 10$ & 0.0399 & -0.0035 & -0.3247 & 0.7400 \\
\hline $08 \times 11$ & 0.0171 & -0.1190 & 0.6531 & -0.0465 \\
\hline $08 \times 12$ & 0.0357 & -0.0695 & -0.0346 & 0.5525 \\
\hline $09 \times 10$ & -0.0201 & -0.0800 & -0.4766 & 0.1230 \\
\hline $09 \times 11$ & -0.1034 & 0.0680 & 0.5652 & 0.2155 \\
\hline $09 \times 12$ & 0.1681 & -0.0715 & -0.5955 & -0.2175 \\
\hline $10 \times 11$ & -0.0738 & 0.2235 & -0.6123 & 0.2465 \\
\hline $10 \times 12$ & -0.0057 & 0.0505 & 1.2913 & 1.4980 \\
\hline $11 \times 12$ & 0.0087 & 0.0230 & -0.1167 & -0.4495 \\
\hline $\mathrm{SD}^{4}(\mathrm{Sij})$ & 0.4522 & - & 0.4522 & - \\
\hline SD(Sij-Sik) & 0.6708 & - & 0.6708 & - \\
\hline SD(Sij-Skl) & 0.6324 & - & 0.6324 & - \\
\hline$S D(R i j)$ & - & 0.5000 & - & 0.5000 \\
\hline
\end{tabular}

${ }^{1 S C A}$ : specific combining ability; ${ }^{2} \mathrm{ERP}$ : efficiency of use of $A$. brasilense for relative ear position; ${ }^{3} \mathrm{EGY}$ : efficiency of use of A. brasilense for grain yield; ${ }^{4} \mathrm{SD}$ : standard deviation.

Reciprocal diallel crosses had no significant effect on the traits under study. This prevented the determination of the genotypes to be used as male and female parents in hybridization aiming to obtain efficient genotypes regarding the use of Azospirillum (Tables 7 and 8). The results of the crosses and their reciprocals were statistically equal, meaning that nuclear genes probably control the inheritance of these traits. Therefore, there is no maternal inheritance in their determination (Cruz \& Regazzi, 2014). The minimum and maximum values for the reciprocal crosses were, respectively: -0.125 (06x07) and $0.225(02 \times 12)$ for EPH; $-0.182(03 \times 07)$ and $0.2975(02 \times 12)$ for $\mathrm{EEH} ;-0.165$

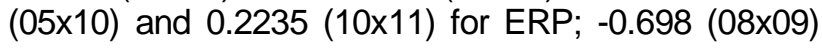
and $2.118(05 \times 06)$ for EGY. The highest amplitude value is 2.816, corresponding to EGY.

Among the 66 crosses, 36 showed positive values and 30 showed negative values for EPH. For $\mathrm{EEH}, 34$ crosses showed positive values and 32 showed negative values. For ERP, 32 crosses showed 
positive values and 34 showed negative values. For EGY, 37 crosses showed positive values and 29 showed negative values.

In the experiment by Buzinaro et al. (2018), the estimates for the effects of GCA for efficiency to Azospirillum in plant height, ear height, and grain yield, as well as for the effects of SCA for efficiency in grain yield, were significant. The authors concluded that additive effects influence the genetic control of the three traits in question, and that nonadditive effects influence the genetic control of the trait grain yield.

These contrasting results are understandable since GCA and SCA estimates are relative measures of the genotypes. These estimates thus depend on the population groups and evaluation conditions of each experiment, and may also suffer from environmental interference (Griffing, 1956).

Taken in isolation, the results of the present study are interesting for genetic breeding programs that aim at efficiency in the use of Azospirillum brasilense. As there is no maternal inheritance for these traits, only half of the genotypes need to be evaluated in the field since the study design can exclude reciprocal crosses (Bordallo, 2005; Cruz \& Regazzi, 2014).

Paternianini \& Campos (2005) described all the stages of a maize breeding program, highlighting the evaluation of the combining ability of genotypes. This stage includes the use of many materials in the field, demanding more investment, labor, and time. Removing the reciprocal of each cross for field evaluations optimizes costs and time.

\section{Conclusions}

There is no maternal inheritance for the efficiency of use of Azospirillum brasilense regarding plant height, ear height, relative ear position, and grain yield, indicating that nuclear genes govern these traits.

For these traits, there is no need to evaluate reciprocal crosses in the field, which optimizes resources and time in genetic breeding programs.

This study identified efficient genotypes for the use of Azospirillum brasilense for all traits under study. The most responsive genotypes regarding grain yield efficiency were: $6,11,15,17,31,56,92,102,103,105$, 118 , and 121.

\section{References}

Akhtar K, Afridi MZ, Akbar M, Zaheer S, Faisal S (2015) Planting densities and nitrogen level impact on yield and yield component of maize. Pure and Applied Biology 4(2):217. doi: 10.19045/bspab.2015.42010.

Amaral CB, Oliveira GHF, Môro GV (2018) Phenotyping open-pollinated maize varieties for environments with low nitrogen availability. Archives of Agronomy and Soil Science, v. online: p. 1-8. doi: 10.1080/03650340.2018.1442574.
Bordallo PN, Pereira MG, Amaral Júnior AT, Gabriel APC (2005) Análise dialélica de genótipos de milho doce e comum para caracteres agronômicos e proteína total. Horticultura Brasileira 23(1):123-127. doi: 10.1590/S0102-05362005000100026

Brusamello-Santos LC, Gilard F, Brulé L, Quilleré I, Gourion B, Ratet P (2017) Metabolic profiling of two maize (Zea mays L.) inbred lines inoculated with the nitrogen fixing plant-interacting bacteria Herbaspirillum seropedicae and Azospirillum brasilense. Plos One 12(3):1-19. doi: 10.1371/journal.pone.0174576

Buzinaro R, Oliveira GHF, Amaral CB, Souza Júnior CL, Môro GV (2018) Diallel mixed-model analyses to select superior maize parental lines for Azospirillum brasilense and nitrogen-use efficiency. Crop Breeding and Applied Biotecnology 18(4):382-389. doi: 10.1590/1984$-70332018 \mathrm{v} 18 \mathrm{n} 4 \mathrm{a} 57$

Companhia Nacional de Abastecimento (2018) Séries históricas das safras. Disponível em: < https://www.conab.gov.br/info-agro/safras/serie-historica-das-safras?start=20 > (Acesso em: 28 jun 2020).

Cruz CD, Regazzi AJ (2014) Modelos biométricos aplicados ao melhoramento genético. UFV. 668p.

Ferreira Majf, Braz LT, Queiroz MA, Churata-Masca MGC, Vencovsky R (2002) Capacidade de combinação em sete populações de melancia. Pesquisa Agropecuária Brasileira 37(7):963-970. doi: 10.1590/S0100-204X2002000700010.

Fischer KS, Johnson EC, Edmeads GO (1983) Breeding and selection for drought resistance in tropical maize. CIMMYT. 16p.

Griffing B (1956) Concept of general and specific ability in relation to diallel crossing systems. Australian Journal of Biological Sciences 9(4):462- 93.

Han M, Okamoto M, Beatty PH, Rothstein SJ, Good AG (2015) The genetics of nitrogen use efficiency in crop plants. Annual Review of Genetics 49:269-289. doi: 10.1146/annurev-genet-112414-055037.

Hungria M (2011) Inoculação com Azospirillum brasilense: inovação em rendimento baixo custo. Embrapa Soja. 36p.

Köppen W (1948) Climatología: Con un estudio de los climas de la Tierra Fondo de cultura economica. 478p.

Montañez A, Abreu C, Gill PR, Hardarson G, Sicardi M (2008) Biological nitrogen fixation in maize (Zea mays L.) by $15 \mathrm{~N}$ isotope-dilution and identification of associated culturable diazotrophs. Biology and Fertility of Soils 45:253-263. doi: 10.1007/s00374-008-0322-2.

Paterniani E, Campos MS (2005) Melhoramento do milho. In: Borém A. Melhoramento de espécies cultivadas. UFV. $4 p$. 
Pereira LC, Tozoni ML (2017) Inoculação de estirpes de Azospirillum brasilense associado à fertilização nitrogenada na cultura do milho. Revista Científica Eletrônica de Agronomia 31:1-12

Pereira LM, Pereira EM, Revolti LTM, Zingaretti SM, Môro GV (2015) Seed quality, chlorophyll content index and leaf nitrogen levels in maize inoculated with Azospirillum brasilense. Revista Ciência Agronômica 46(3):630-637.

Pereira-Defilippi L, Pereira E M, Silva F M, Môro GV (2017) Expressed sequence tags related to nitrogen metabolism in maize inoculated with Azospirillum brasilense. Genetics and Molecular Research 16(2):1-14. doi: $10.4238 / g m r 16029682$
Revolti LTM, Caprio CH, Mingotte FLC, Môro GV (2018) Azospirillum spp. potential for maize growth and yield. African Journal of Biotechnology 17(18):574-585. doi: /10.5897/AJB2017.16333.

Wasaya A, Tahir M, Ali H, Hussain M, Yasir TA, Sher A, ljaz M (2017) Influence of varying tillage systems and nitrogen application on crop allometry, chlorophyll contents, biomass production and net returns of maize (Zea mays L.). Soil and Tillage Research 170:18-26. doi: 10.1016/j.still.2017.02.006 